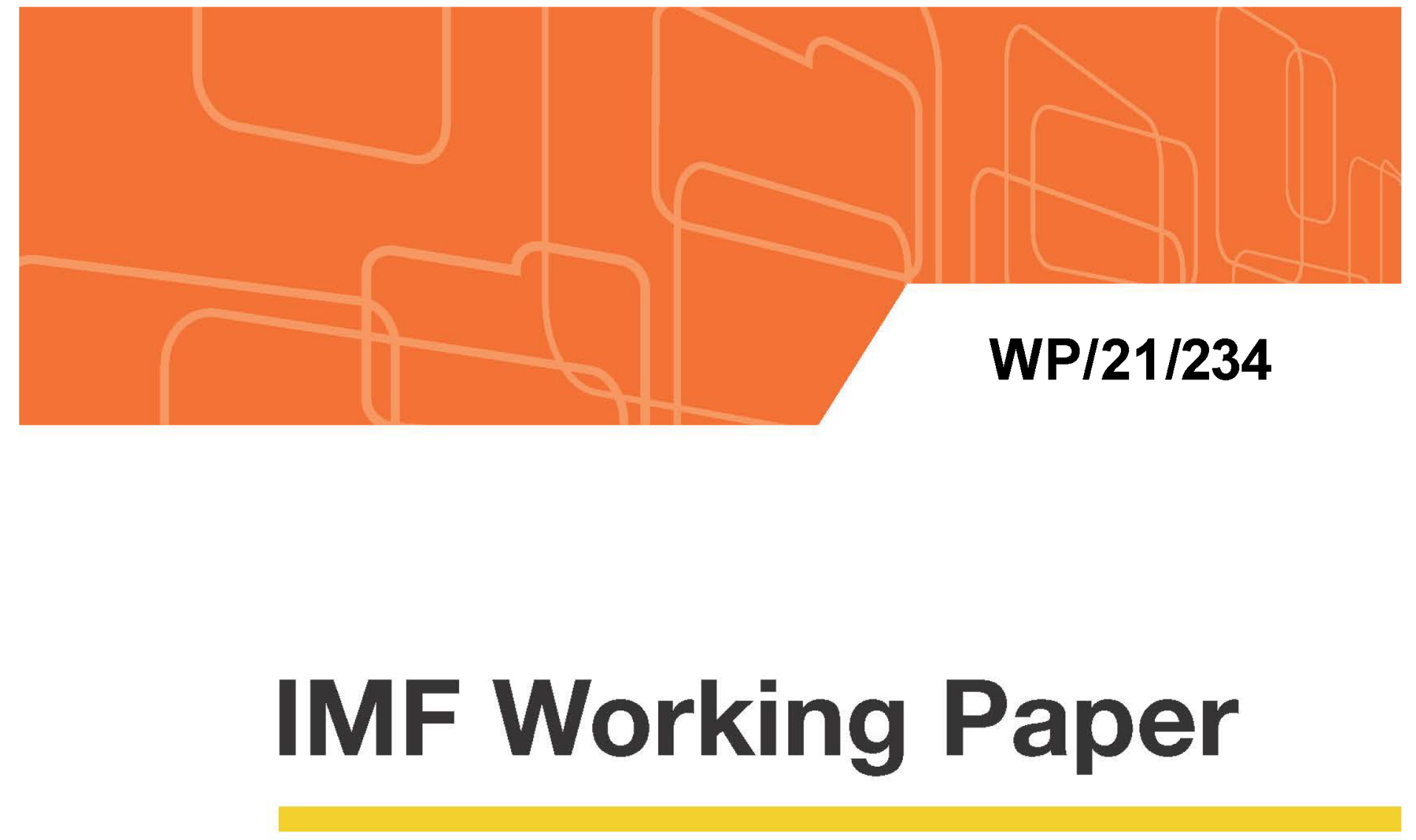

\title{
Growth at Risk from Natural Disasters
}

by Tamim Bayoumi, Saad Noor Quayyum, Sibabrata Das

IMF Working Papers describe research in progress by the author(s) and are published to elicit comments and to encourage debate. The views expressed in IMF Working Papers are those of the author(s) and do not necessarily represent the views of the IMF, its Executive Board, or IMF management. 


\title{
IMF Working Paper
}

Strategy, Policy and Review Department

Growth at Risks from Natural Disasters

Prepared by Tamim Bayoumi, Saad Quayyum and Sibabrata Das ${ }^{1}$

Authorized for distribution by Johannes Wiegand

September 2021

\section{IMF Working Papers describe research in progress by the author(s) and are published to elicit comments and to encourage debate. The views expressed in IMF Working Papers are those of the author(s) and do not necessarily represent the views of the IMF, its Executive Board, or IMF management.}

\begin{abstract}
The paper analyzes the impact of natural disasters on per-capita GDP growth. Using a quantile regressions and growth-at-risk approach, the paper examines the impact of disasters and policy choices on the distribution of growth rather than simply its average. We find that countries that have in place disaster preparedness mechanisms and lower public debt have lower probability of witnessing a significant drop in growth as a consequence of a natural disaster, but our innovative methodology in this paper finds that the two policies are complements since their effectiveness vary across different disaster scenarios. While both are helpful for small to mid-size disasters, lower debtand hence more fiscal space - is more beneficial in the face of very large disasters. A balanced strategy would thus involve both policies.
\end{abstract}

JEL Classification Numbers: E62, E63, H6, O4, Q54

Keywords: Growth, Growth at Risks, Disaster Preparedness, Public Debt

Author's E-Mail Address: tamim.bayoumi@gmail.com, squayyum@imf.org, sdas@imf.org

\footnotetext{
${ }^{1}$ We would like to thank Tamim Bayoumi, Stefania Fabrizio, Kangni Kpodar, Ali Mansoor for comments and suggestions, and Sheheryar Malik for helping to plot the conditional probability density functions.
} 
Table of Contents
Abstract

I. Introduction

II. Literature Review

III. Data and Stylized Facts

A. Methodology

IV. Results

A. Growth and Disaster Preparedness

$\underline{12}$

B. Growth and Public Debt

V. Conclusion

References

Appendix I

Figures

Figure 1. Natural Disasters on the Rise

Figure 2. Damage from Natural Disasters: 1961-2016

Figure 3. People Affected by Natural Disasters: 1961-2016

Figure 4. Large Natural Disasters: 1992-2016

Figure 5. Growth Around Large Natural Disasters 9

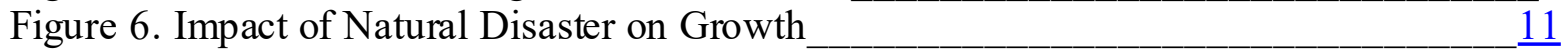

Figure 7. Impact on Growth by Disaster Type ___

Figure 8. Median Impact of Natural Disaster on Growth_________________

Figure 9. Impact of Natural Disaster on Growth for Various Levels of Disaster ___

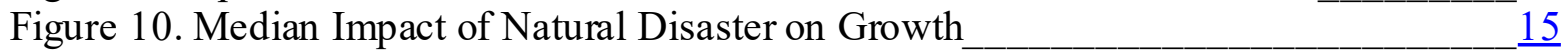

Figure 11. Natural Disaster, Public Debt and Growth Distribution _______

\section{Tables}

Table 1. Impact of Natural Disaster on Growth in the Year of Disaster

Table 2. Impact of Large Natural Disaster on Growth by Disaster Type

Table 3. Disaster Preparedness and Impact of Natural Disaster on Growth 22

Table 4. Public Debt and Impact of Natural Disaster on Contemporaneous Growth___

Table 5. Public Debt and Impact of Natural Disaster on Growth in Years after Disaster

Table 6. Investment Growth and Natural Disaster 


\section{INTRODUCTION}

Worldwide attention has been drawn to the destructions from natural disasters in recent years, especially after major events such as the Tsunami in the Indian Ocean in 2004, Hurricane Katrina in 2005, earthquakes in Haiti and Chile in 2010, and in Nepal 2015, and Category 4 \& 5 storms in the Bahamas, Dominica, Fiji, Vanuatu, and other small states over 2012-2019. Large natural disasters can cause significant damage with severe adverse macroeconomic effect. In 2017, the estimated losses in Dominica from a major hurricane was over 220 percent of GDP and the economy shrank 9 percent a year over $2017-18 .{ }^{2}$

The frequency and intensity of natural disaster have increased over time and are projected to increase further with climate change (see Figure 1). Indeed, increased wildfire in the western parts of the United States and floods in central Europe attest to these risks. The number of category 4 and 5 storms in the North Atlantic is expected to increase by 45 to 87 percent over the course of $21^{\text {st }}$ century, and weather events such as flood, coastal inundation, drought and cyclones are expected to intensify in the Pacific compounding the economic challenges already faced by the small states in these regions. ${ }^{3}$ Moreover, changing climate patterns can cause natural disasters to strike places that have not experienced such events before and are hence unprepared (Hallegatte 2007; Kossin, Emanuel, and Vecchi 2014).

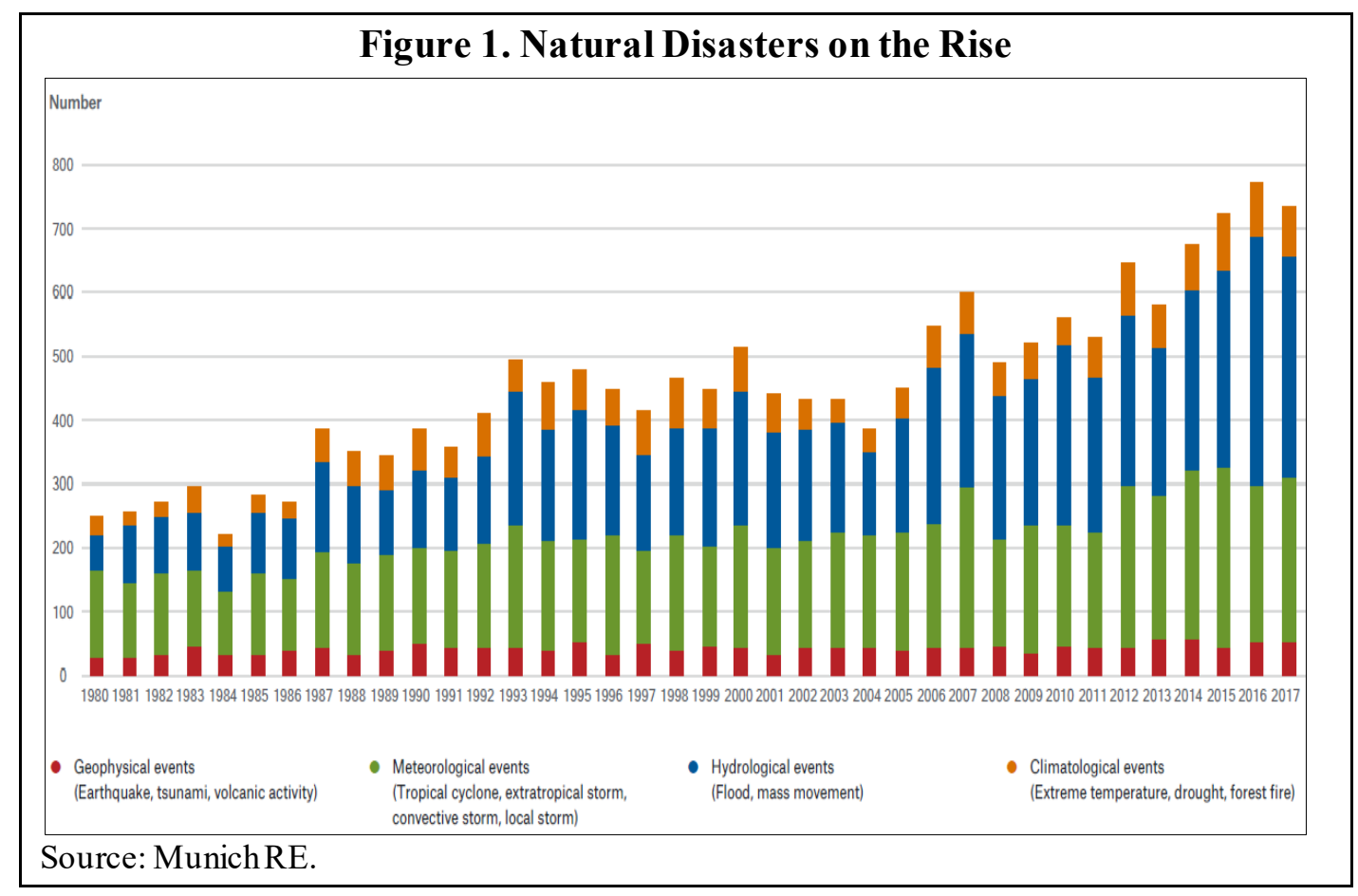

\footnotetext{
${ }^{2}$ Dominica Article IV Staff Report (IMF 2018)

${ }^{3}$ Data on the North Atlantic are from Center for Climate and Energy Solutions based on Knutson and others (2013); information on the Pacific is from the World Bank (2017) Report Pacific Possible
} 
Understanding and quantifying the macroeconomic impact of natural disasters is particularly important to allow policy makers to allocate resources appropriately. In particular, it can help policy makers to decide how much to spend for building ex-ante resilience through better physical infrastructure and how much fiscal space to preserve to deal with the aftermath of a disaster, depending on the type of risk they face. ${ }^{4}$ Understanding how much growth is at risk from natural disaster can factor in a government's decision of how much insurance to buy (see IMF 2019) and how much to allocate for contingency spending in the budget. Given that a sharp slowdown in growth may undermine financial sector stability, growth at risk from natural disaster can also influence financial sector policies including macroprudential policies.

In this paper, we explore the impact of natural disaster on growth of GDP per capita through a "growth-at-risk" approach using quantile regressions. ${ }^{5}$ We use the regression coefficients to estimate the conditional probability density function and the associated probability of growth declining below zero, when a country is hit by a large natural disaster. Moreover, we identify how disaster preparedness and lower public debt help mitigate the impact of large natural disaster on growth, and how these factors affect the probability-distribution of growth outcomes. For disaster preparedness, we construct an index using data provided by UNISDR for a group of 120 countries over the period 2007-2015. We find that higher disaster preparedness is associated with lower decline in growth from a natural disaster. Our results also show that countries with lower public debt levels are less likely to see a sharper decline in growth and experience faster recoveries when hit by a large natural disaster. This effect seems to be driven by investment, as investment growth following a disaster appears to be higher in countries with lower debt. This likely reflects that countries with lower debt have more fiscal space to borrow to rebuild destroyed infrastructure.

On the policy side, our findings suggest a large payoff both to investing in disaster preparedness and structural resilience to natural disasters and to following prudent fiscal management and building fiscal buffers to manage the risks from natural disasters (building financial resilience to disasters). In addition, our findings suggest that policy makers should consider tailoring their policy response to the type of risks facing them. While higher disaster-preparedness appears to mitigate the impact of disasters on growth for smaller disasters with lowers effects on growth, it provides little or no benefit for large natural disasters (associated with large losses in growth). Fiscal space measured by lower public indebtedness, on the other hand, appears to be more effective in mitigating the impact of a high intensity event on growth. This makes intuitive sense, as high intensity events can cause significant damage even in the most prepared economies with the most advanced structures

\footnotetext{
${ }^{4}$ See IMF (2019) and Guo and Quayyum (2020) for discussions on building ex-ante resilience to natural disasters i.e., actions that can be taken now to reduce the impact of natural disasters in the future.

${ }^{5}$ See Adrian and others 2018 and 2019.
} 
and building codes. In such cases, it is important to have fiscal resources readily available to rebuild the economy and minimize adverse impact on growth.

\section{LITERATURE REVIEW}

Neither the neoclassical growth models, nor the endogenous growth models have any clearcut answers to the question on the impact of natural disasters on growth (Cavallo and others 2013, Caballero and Hammour, 1994). Researchers have tried to find the answer through empirical investigation. A number of papers have estimated the mean impact of natural disasters on growth. Noy (2009) found that natural disasters had an adverse effect on growth and this effect was more pronounced in developing and small countries. Adverse impact of natural disasters was also found by Noy and Nualsri (2007), Raddatz (2009), and Loayza and others (2012). Indeed, there is an emerging consensus on the negative effect on macroeconomic growth in the short-term (Rodriguez-Oreggia and others 2013;Cavallo and Noy 2011; Hochrainer 2009; Mechler 2009). By contrast, findings on the long run impact vary across studies. ${ }^{6}$

Marto and others (2018) use a dynamic small open economy model to study the macroeconomic effects of natural disasters and investment in resilient infrastructure. They find that investing in resilient infrastructure can have high payoffs if they are complementary to standard capital but can lead to debt sustainability concerns. Using a dynamic stochastic general equilibrium model Cantelmo and others (2019) find that disasters lead to significant welfare losses. They also find that self-financing resilient infrastructure improve welfare only modestly in disaster prone countries, and hence advocate grant financing for resilient building.

Given that the small island states are especially vulnerable to natural disasters, papers have also focused on the impact of natural disasters in the Pacific and Caribbean regions. Lee, Zhang, and Nguyen (2018) estimated the impact of large disasters on growth for Pacific island countries. They found that large disasters have significant negative effect of growth, and fiscal and trade balances. Strobl (2012) explored the impact of hurricane in Central America and Caribbean regions and found that on average they lead to reduction in growth of 0.83 percent.

This paper uses the growth-at-risk methodology developed by Adrian and others (2018a and 2018 b) and used in IMF (2017) to study how conditional distribution of GDP growth varies with economic and financial conditions. This is the first application of this methodology to analyze the impact of natural disasters on growth. While the current papers in the literature focus on estimating the mean impact of natural disaster on growth, this paper estimates the

\footnotetext{
${ }^{6}$ In a cross-sectional, long-run study Skidmore and Toya (2002) found a positive correlation between, output growth and natural disaster frequency. However, Raddatz (2009) found an adverse long run effect of natural disaster on output growth using panel times series techniques. Focusing only on droughts, Berlemann and Wenzel (2016) also find adverse long-term growth effects of natural disaster.
} 
impact of natural disaster on various quantiles of growth. By focusing on the mean, researchers ignore risks around the central forecast, and underestimate risks, especially tail risks, which are important for natural disasters. The growth-at-risk methodology allow us to explore how mitigation mechanisms (disaster preparedness, indebtedness) affects different part of the growth distribution including tail risks. ${ }^{7}$ Importantly, our new approach reveals that the two policies are complements, affecting different part of the distribution of growth risks after a disaster.

\section{DATA And STylized FACTS}

The data for natural disasters is from EM-DAT (2018). ${ }^{8}$ The database documents the number of people affected, number of deaths and total damage in U.S. dollar terms from different types of disasters which affect 10 people or more. In this paper, we only consider the disasters that can be classified as natural: flood, drought, storm, earthquake, landslides, volcanic activity, wildfire, and extreme temperatures. Furthermore, we restrict the sample to developing countries where coping mechanisms to natural disasters are more limited than advanced economies.

The distribution for disasters is highly skewed (see Figure 2 and 3 ). In this paper, we focus on large natural disasters where the number of people affected (including the number of deaths) as percentage of previous year's population or the total damage as a percent of previous year's GDP exceeds the $90^{\text {th }}$ percentile. ${ }^{9}$ For many natural disasters EM-DAT database report either the total number of people affected or total damage, and not both. By using the above definition, we are able to include episodes of large disasters, where at least one of impact measures (damage or people affected) are available. Figure 4 below shows the frequency of the different types of large disasters as defined above. Among a total of 277 episodes in the sample, storm, flood, and drought are the most frequent.

Typically, after a large disaster which affects productive capacity, growth falls sharply. Figure 5 shows the impact of large disasters in selected countries. For each country on our database, we first identify the largest disasters. Then we restrict the sample to only countries where the largest disaster caused damages of 20 percent of GDP or higher. Then we plot the cross-country average of growth around the time of disasters for this restricted sample. The figure shows that a large natural disaster is associated with a sharp decline in growth in the year of the disaster, but that growth begins to recover the following year as the rebuilding process starts. The recovery would probably be larger (as it is for the next year) if it were not

\footnotetext{
${ }^{7}$ To the best of our knowledge other papers in the literature have not explored this before.

${ }^{8}$ This is the most widely used data on natural disasters which covers where disaster incidents are reported if the event leads to i) 10 or more deaths, ii) 100 or more people affected, iii) declaration of state of emergency or iv) call for international assistance. The database however may suffer from underreporting problems in earlier years.

${ }^{9} \mathrm{The} 90^{\text {th }}$ percentile for the total number of people affect (including number of deaths) as a percent of total population was 8.3 percent. The $90^{\text {th }}$ percentile for the total damage as a percent of GDP was 2.9 . We also check the robustness of the result using a threshold of $75^{\text {th }}$ percentile to define large disasters. The results are qualitatively the same, although the magnitude of the impact of the natural disasters on growth is less.
} 
for the fact that our annual data include some disasters "late" in the calendar year, which continue to have major effect through the next year.
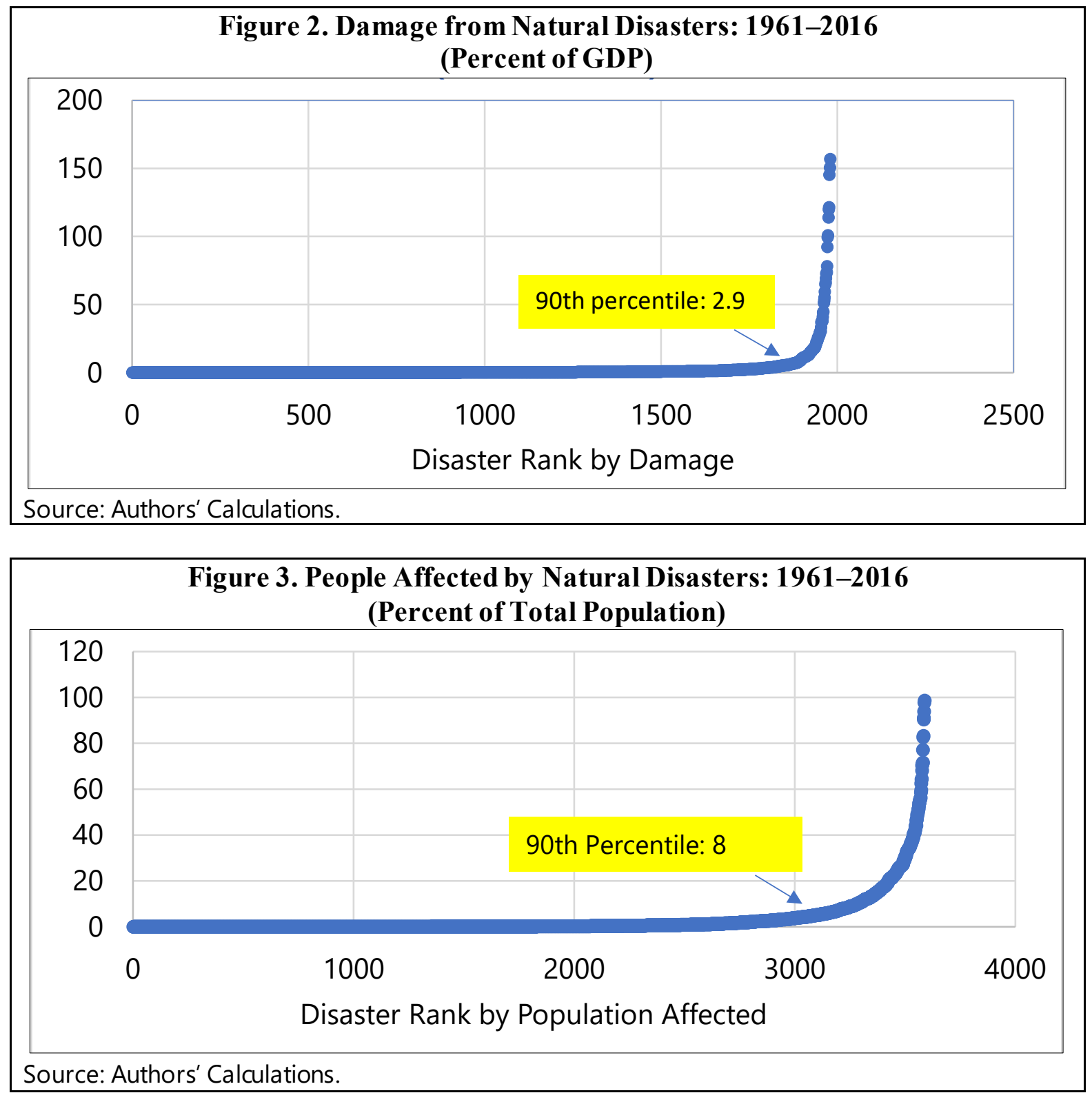
Figure 4. Large Natural Disasters: 1992-2016

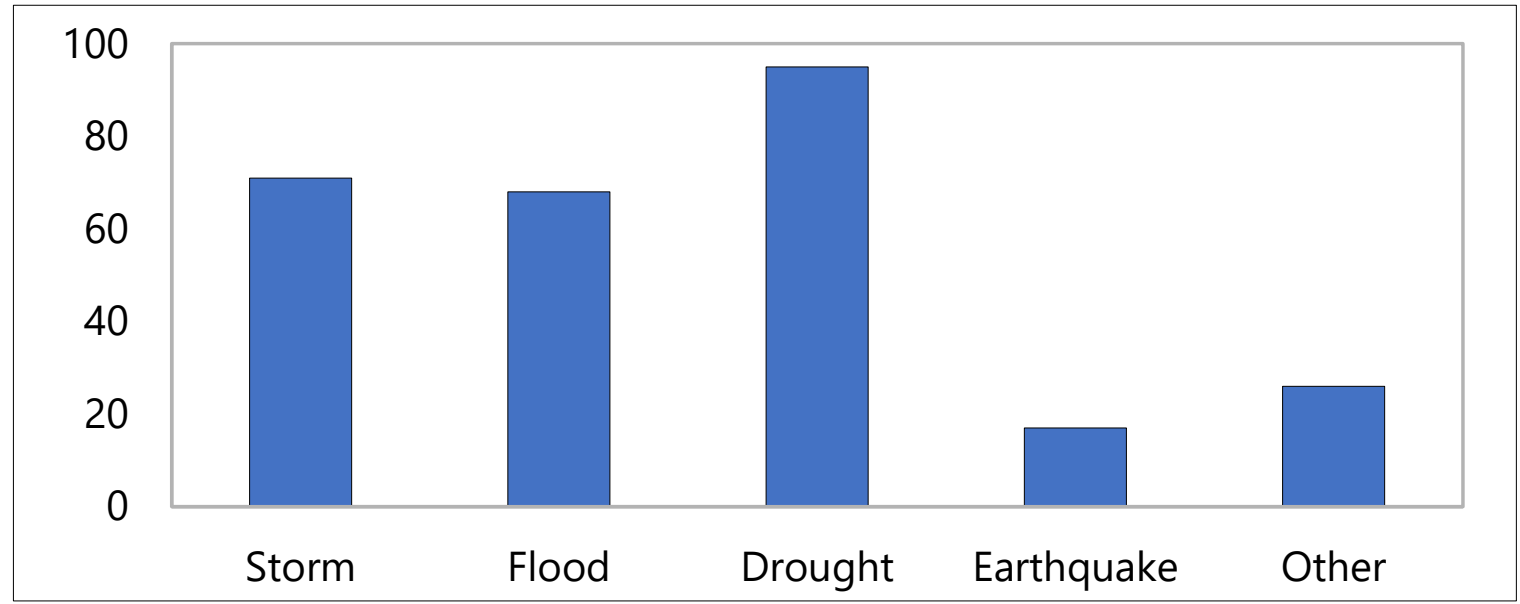

Source: EMDAT Database, 2018.

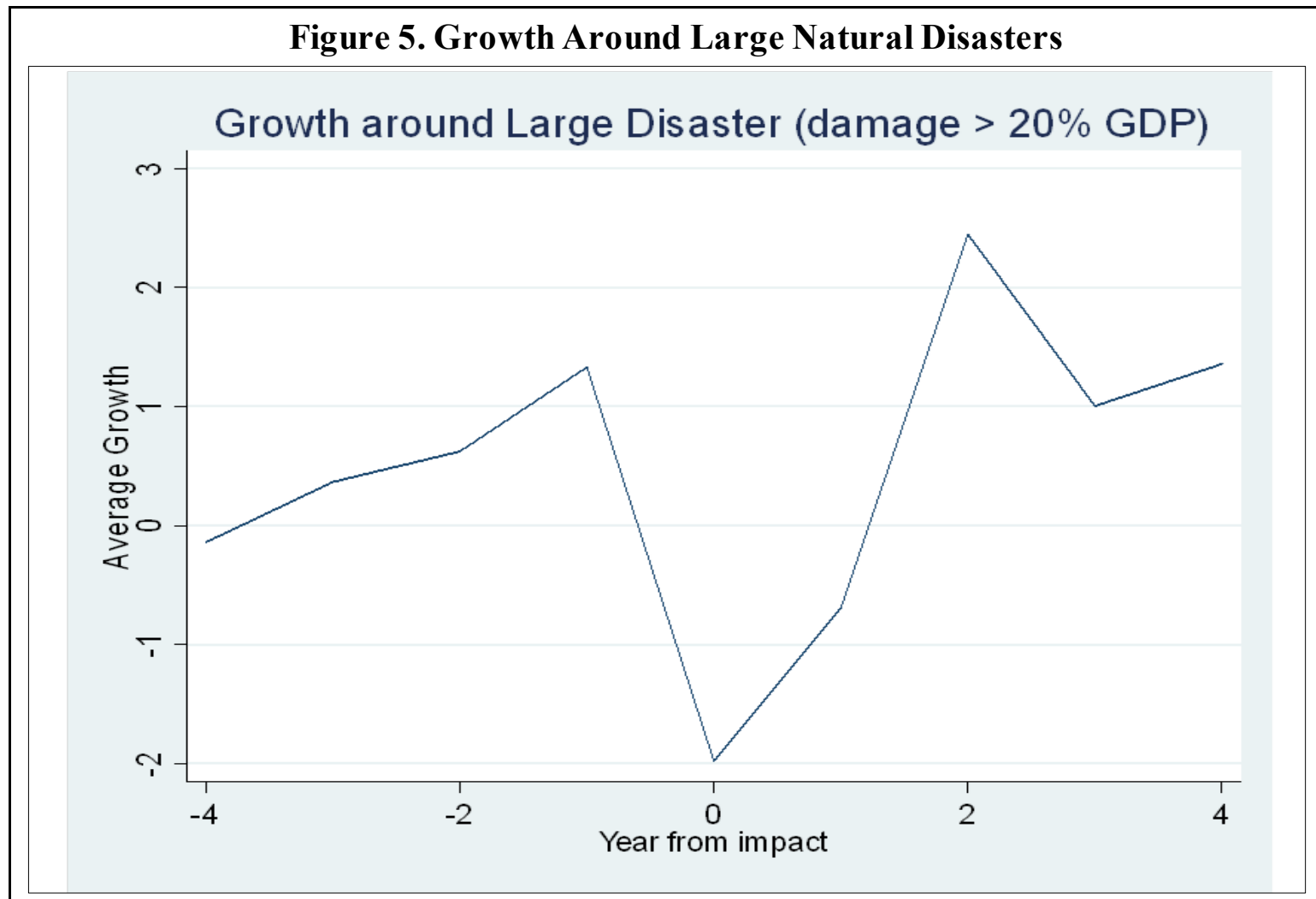

Source: EM-DAT database, 2018; and authors' calculations.

Note: Average growth of GDP per capita for 15 episodes in developing countries between 1991 to 2016. 


\section{A. Methodology}

To investigate the impact of natural disasters on growth, we estimated the following model using quantile regressions:

$Y_{i, t, q}=\theta_{q}+\alpha_{q} Y_{i, t-1}+\beta_{q} X_{i, t}+\gamma_{q} N_{i, t}+\delta_{q} X_{i, t} N_{i, t}+\lambda_{t}+\mu_{i}+\epsilon_{i, t, q}^{h}$

$Y_{i, t+h, q}$ is the growth of GDP per capita over at time $\mathrm{t}$ for country $i$ for quantile $q .{ }^{10} N_{i, t}$ is a variable which takes the value of 1 if the country is hit by a large natural disaster as defined above and is zero otherwise. $X_{i, t}$ capture country features that may influence how natural disaster affects growth. In particular, we include a measure of disaster preparedness and the level of public debt as a percent of GDP. Higher level of disaster preparedness can significantly lower the impact of a natural disaster on growth. Fiscal space (as captured by the level of public debt) can influence how quickly and effectively a country can recover after a disaster. Lack of fiscal space can constrain a country from borrowing to finance critical infrastructure projects. We keep the specification simple with few covariates as large number of covariates can lower the identification power, especially for extreme quantiles.

To measure disaster preparedness, we construct an index from data on the Hyogo Framework Action (henceforth called HFA Index). The Hyogo Framework Action laid out five key priority areas for building disaster resilience: i) ensure disaster risk reduction is a national and a local priority with a strong institutional basis for implementation; ii) identify, assess and monitor disaster risks and enhance early warning; iii) use knowledge, innovation and education to build a culture of safety and resilience at all levels; iv) reduce underlying risks factors; and v) strengthen disaster preparedness for effective response at all levels. Countries reported their progress on each of these five criteria in a scale of 1 to 5. Data for this is available from UNISDR for the period 2007-2015. To construct the HFA index, we added the aggregate scores for five priorities for each of the countries in our sample. The index ranges from a maximum value of 25 to a minimum of 0 , with higher number indicating more preparedness. The median value in our sample of developing countries was 16 , and the $10^{\text {th }}$ and $90^{\text {th }}$ percentiles 12 and 20 respectively.

Quantile regressions have the advantage that they allow us to estimate the impact of the natural disaster on different points of conditional distribution of growth and not just the mean. The method is also more robust to outliers. We estimate the model using Powell (2015)'s quantile regression estimator for panel data which allows us to control for country and year fixed effects. We estimate the conditional probability distribution of growth using the smoothing mechanism on the quantile estimates as in IMF (2017) (see Annex I). The conditional probability distribution allows us to estimate the probability of growth declining

${ }^{10} \mathrm{GDP}$ per capita is purchasing power parity adjusted is from the World Economic Outlook database. 
below any threshold. For the purpose of this paper, we estimate the probability of growth falling below zero.

\section{RESUlts}

Figure 6 shows the impact of a large natural disaster on growth. The impacts plotted are the estimates of the coefficient on natural disaster from the regression with only natural disaster and lagged growth as the explanatory variable (see Table 1). In these regressions we include year fixed effects to control for time and country specific factors that may affect growth. A large natural disaster reduces growth by 0.7 percent in the year of the disaster on average. The impact across the growth quantiles do vary, with larger impact on the lower quantiles than the higher. The coefficient of 0.9 on the $10^{\text {th }}$ quantile suggest that there is a 10 percent chance that growth will fall by 0.9 percent when there is a large natural disaster. The estimates suggest that a natural disaster not only shift the growth distribution to the left (towards less growth), but it also shifts the left tail further out.

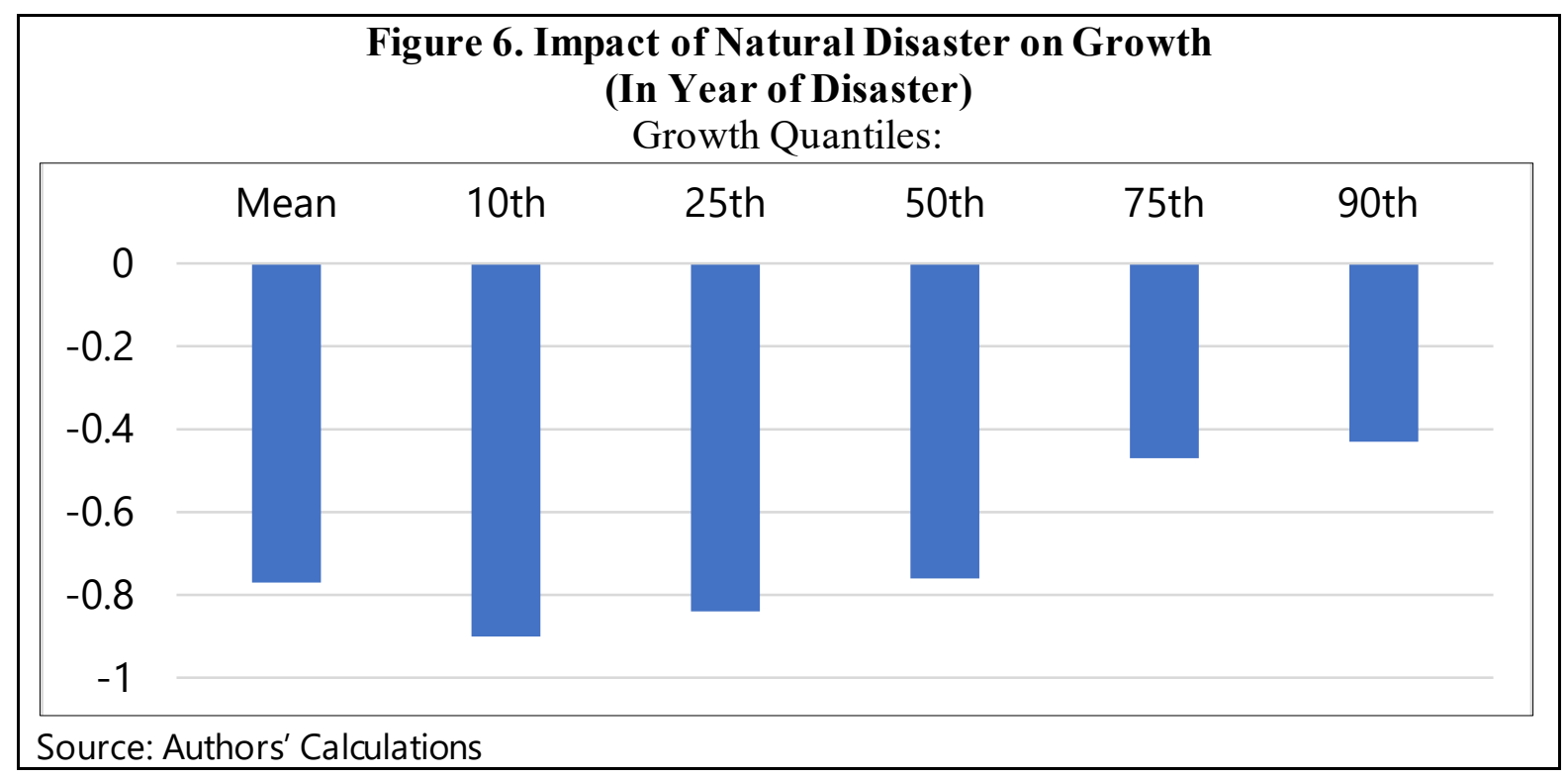

The results are broadly consistent with earlier results from the literature. The impact of natural disaster on growth in the literature varies significantly based on how a natural disaster is defined i.e., what threshold is used for large natural disaster. For example, Felbermayr and Groschl (2014) finds a disaster in the top 1-percentile of their disaster index distribution reduces GDP per capita by at least $6.83 \%$, while the top 5-percentile disasters cause per capita income to drop at least by $0.33 \%$, and the smallest 25 -percentile disasters cut GDP per capita by at most $0.01 \%$. Lee and others (2018) estimate the impact of natural disaster on the 
Pacific islands and finds that large natural disaster - with damages above the $75^{\text {th }}$ percentile tends to reduce GDP growth by an average of 1.8 percentage points. ${ }^{11}$

There is significant heterogeneity across the types of disaster on their impact on growth. Figure 7 shows that droughts have very little impact on growth across the different quantiles. ${ }^{12}$ Storms and floods on the other hand have strong negative impact, across all the quantiles. Earthquakes have large negative impact for the $10^{\text {th }}$ and the $25^{\text {th }}$ quantile and small positive impact for the 50 th quantile. ${ }^{13}$

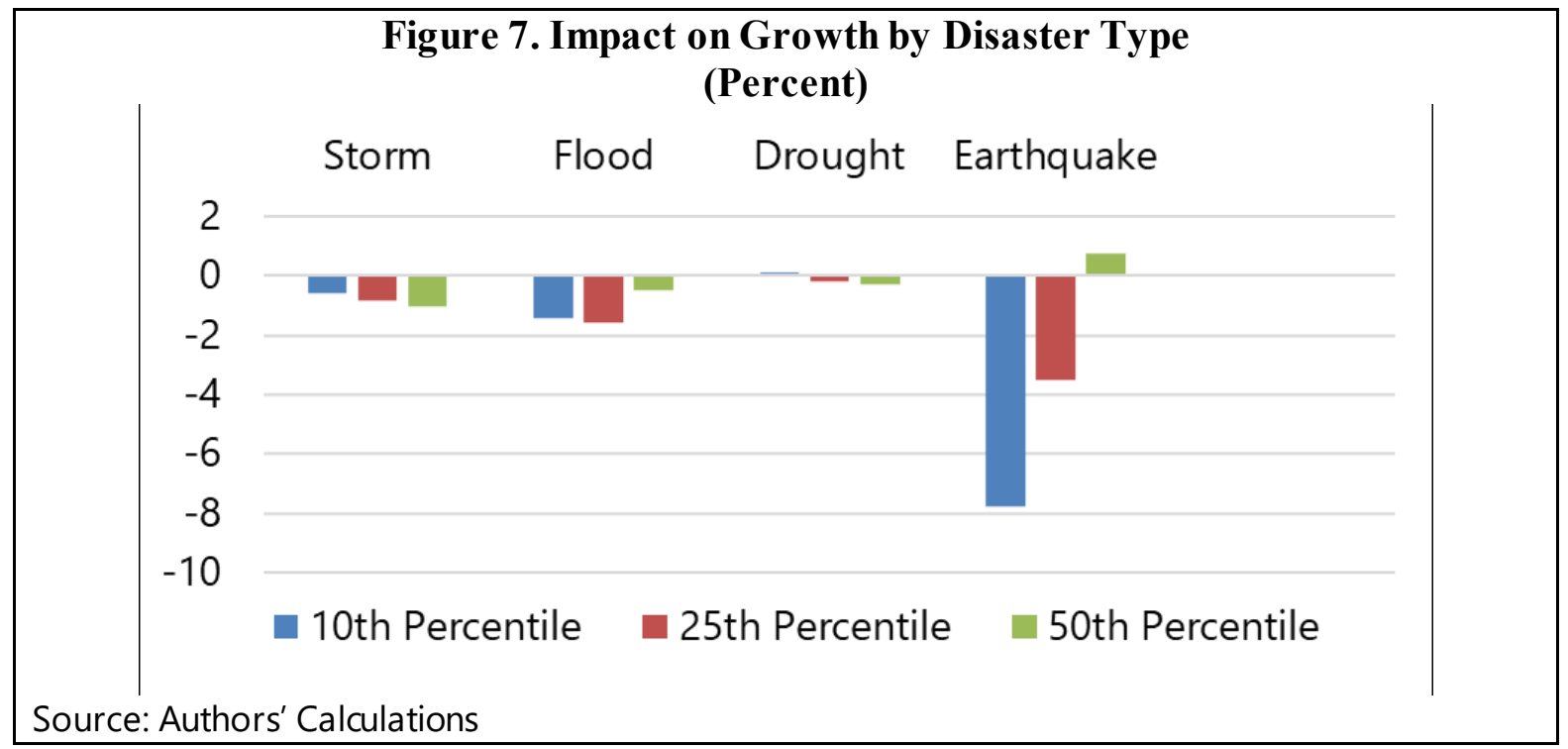

\section{A. Growth and Disaster Preparedness}

The impact of natural disaster on growth can vary significantly depending on the level of disaster preparedness. Table 3 shows the regression results when we introduce the HFA index and its interaction with the natural disaster dummy into the regression model. ${ }^{14}$ The interaction term between HFA index and natural disaster is significant for the $50^{\text {th }}, 7^{\text {th }}$ and $90^{\text {th }}$ quantile. The size of the coefficient for the median regression suggest that the median impact of a large natural disaster can be as high as -3 percent for countries with HFA Index

\footnotetext{
${ }^{11}$ Note that damages from natural disasters in the Pacific island countries are significantly higher than large developing countries.

${ }^{12}$ The underlying regression results are reported in Table 2.

${ }^{13}$ The number of earthquakes in our sample is 18 (see Figure 4) which calls for caution for interpreting the results for earthquakes. However, the results are consistent with Standard and Poor (2015) findings that large (but rare) earthquakes have the most adverse effect on sovereign creditworthiness due to adverse macroeconomic impact compared to other kinds of disasters.

${ }^{14}$ Note that the sample size is significantly smaller from the previous regressions as the HFA index is available from 2007 to 2015 .
} 
below 12 (low level of disaster preparedness) and close to zero or positive for countries with HFA Index of 18 and above (high level of disaster preparedness) (see Figure 8).
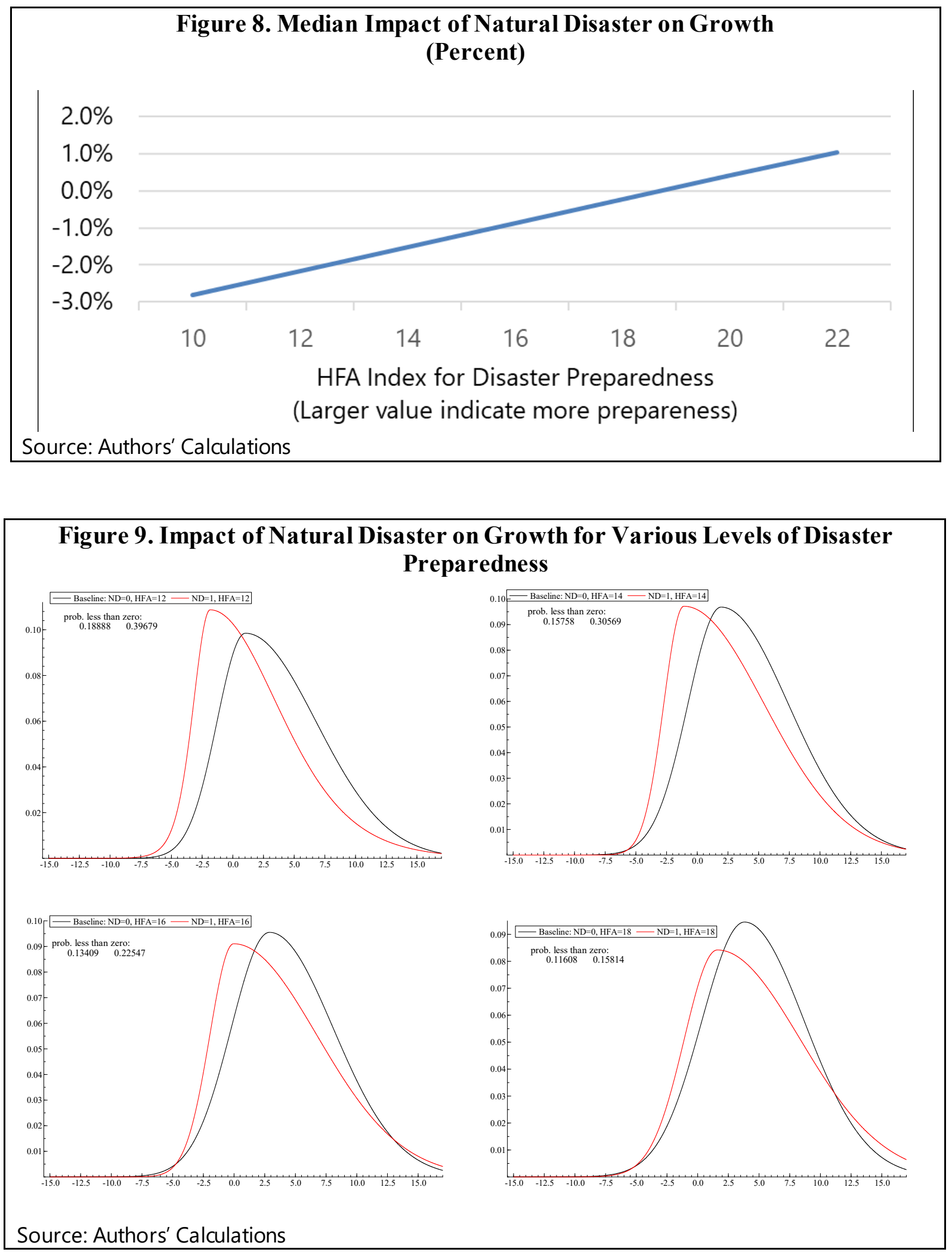

CInternational Monetary Fund. Not for Redistribution 
We estimate the conditional probability density function using the methodology in IMF (2017) (see Annex I) based on these regression coefficients for the different quantiles and plot it for different levels of disaster preparedness. ${ }^{15}$ Figure 9 shows at higher levels of disaster preparedness, the probability of a sharp decline in growth following a large natural disaster diminishes significantly. For a country with HFA Index of 12 , the probability of growth per capita declining below zero more than doubles from about 19 percent to 40 percent, when it is hit by a large natural disaster. On the other hand, for a country at highlevel of disaster preparedness $(\mathrm{HFA}=18)$, the probability of growth per capita declining below zero increases marginally from 12 to 16 percent.

\section{B. Growth and Public Debt}

Fiscal buffers can be important in determining how quickly the country can start the rebuilding process and recover lost productive capacity after a disaster. Countries with little fiscal space may be hesitant or unable to borrow to finance the rebuilding of damaged public infrastructure (to the extent needed).

Table 4 shows the results of introducing log of public debt as a percent of GDP and its interaction with natural disaster dummy. The interaction term is highly significant across the different quantiles (except the $90^{\text {th }}$ ) suggesting that higher debt is associated with lower growth following a natural disaster. Figure below shows how the marginal impact of natural disaster on median growth varies for different public debt levels using the estimates from Table 4 . In the year of a large natural disaster, a country with debt at 60 percent of GDP is likely to experience growth of almost 0.5 percentage lower than a country with debt of 30 percent of GDP.

The results are similar for growth in the years after the disaster. Table 5 reports the regression results for growth one and two year after the disaster. The interaction term is highly significant (and negative) for the $10^{\text {th }}, 25^{\text {th }}, 50^{\text {th }}$ and $75^{\text {th }}$ quantiles when the dependent variable is growth of GDP per capita one year ahead, and for the $25^{\text {th }}, 50^{\text {th }}$ and $75^{\text {th }}$ quantiles when the dependent variable is growth two periods ahead. ${ }^{16}$

\footnotetext{
${ }^{15}$ We estimate the conditional probability density functions for average lagged growth of 2 percent and other parameters as indicated in the chart.

${ }^{16} \mathrm{We}$ also tested specifications with growth three and four periods ahead, but the interaction term was not significant in these specifications.
} 


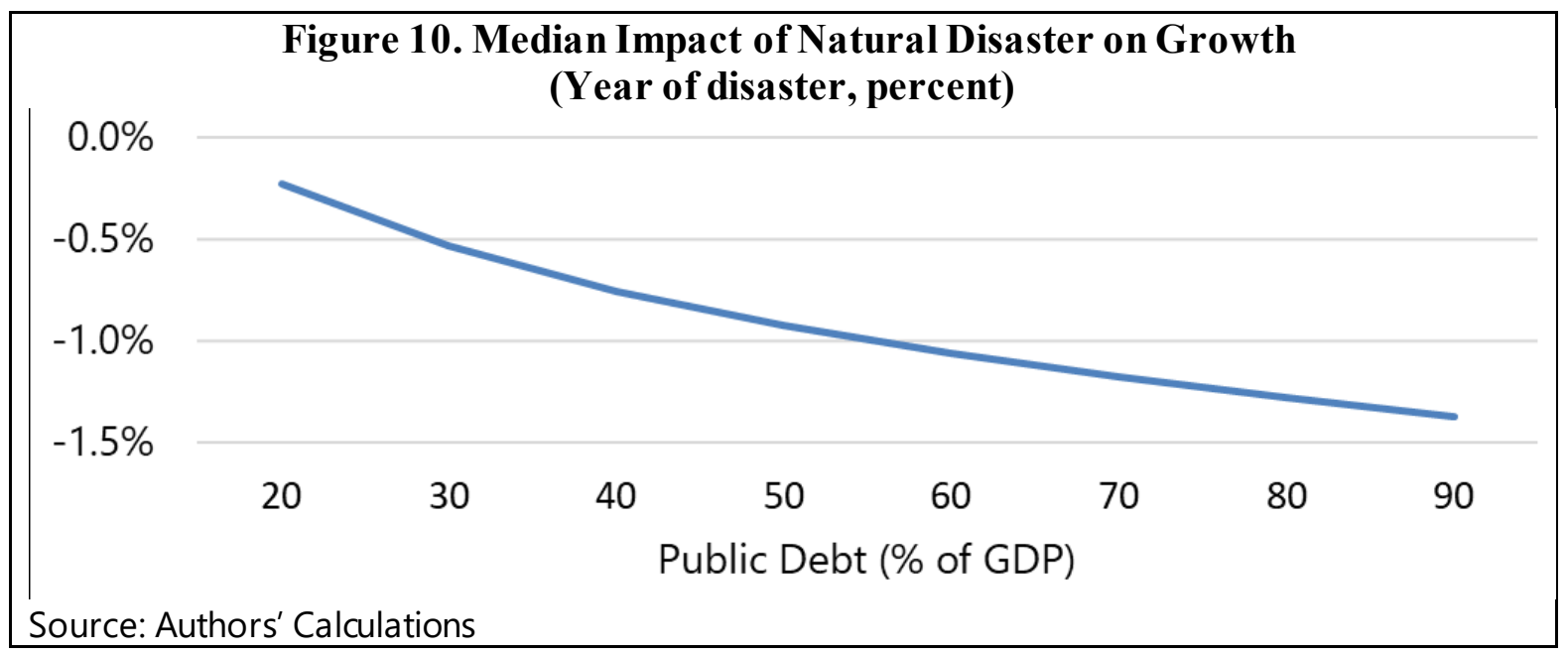

Figure 11 below shows the conditional probability density function of growth of GDP per capita for different debt levels with and without natural disasters based on the parameter estimates in Table $4 .{ }^{17}$ The chart also reports the probability of growth falling below zero. In countries with public debt of 30 percent of GDP the probability of growth declining below zero increases from 0.25 to 0.30 when there is a natural disaster. In countries with public debt of 90 percent of GDP, probability of growth declining below zero increases from 0.26 to 0.42 when there is a natural disaster.

In Table 6, we replace the dependent variable from real GDP per capital growth to real investment growth, as investment is the likely channel through which public debt impacts GDP growth. The results suggest this is indeed the case. The table shows the link between natural disaster and investment in year of the disaster and two years after it. ${ }^{18}$ In the year of the disaster (top panel), the coefficient on natural disaster is positive and significantly associated with investment growth for the median. The impact of natural disaster on investment appears to be much stronger in the year after the disaster (middle panel). Moreover, we continue to see the higher level of debt being associated with lower investment (when there is a natural disaster) from the high significance of the interaction term across four quantiles. Such patterns continue two years from the disaster. ${ }^{19}$

Natural disaster seems to have large impact on investment as one would expect with postdisaster rebuilding, and this effect is large in the years after the disaster. Importantly, higher public debt is associated with lower investment growth following disaster for most quantiles.

\footnotetext{
${ }^{17}$ The underlying quantile regression model is the same as in Table 4 with the exception that debt as percent of GDP was introduced in levels as opposed to logs.

${ }^{18}$ Investment data is from World Development Indicators.

${ }^{19}$ We also tested whether disaster preparedness affected investment growth after a natural disaster. The results however were not conclusive.
} 


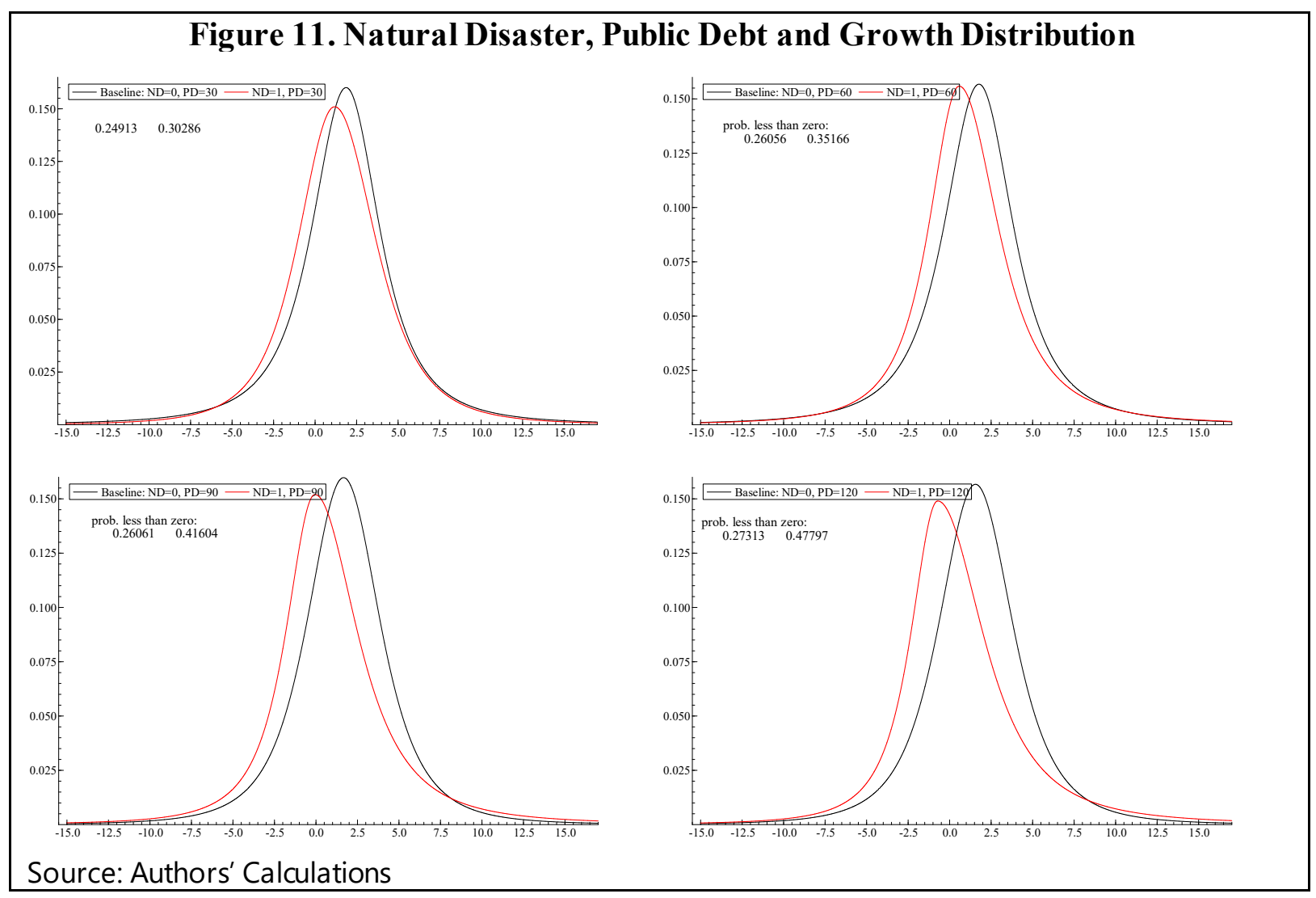

There is interesting difference between the results in Table 3 and Tables 4 and 5 . The coefficients on the interaction between HFA Index and natural disaster are small and not statistically significant from zero for the $10^{\text {th }}$ and $25^{\text {th }}$ quantiles in Table 3 . The interaction terms between public debt and natural disaster for these quantiles are significantly different from zero for the year of the disaster (Table 4) and the following year (Table 5). The results suggest that while disaster preparedness is good at mitigating the impact of medium-to-lower intensity disasters on growth, it is less effective against high intensity disasters. On the other hand, fiscal space is important in mitigating the impact of the higher intensity disasters associated with lower growth. This makes intuitive sense, as our technology is still not at a stage where disaster preparedness (through early warnings, better building codes and more resilient infrastructure) can completely mitigate the impact of truly large disaster on infrastructure and production capacity. Certain amount of damage to infrastructure is expected. The 2019 Hurricane Dorian in the Bahamas and 2011 Tsunami in Japan are good examples. In such cases, having fiscal resources to rebuild the economy is important to mitigate the impact on growth.

\section{Conclusion}

In this paper we explore how much growth of GDP per capita is at risk from large natural disaster. We estimate the impact of natural disasters for different growth quantiles and show 
that impact varies across quantiles, with level of disaster preparedness and fiscal space captured by public indebtedness.

We find that higher disaster preparedness is associated with better growth performance following a natural disaster for median and higher and quantiles that this result is especially significant for small to mid-size disasters. Lower debt is associated with higher investment and output growth following a disaster for most quantiles but is most significant for the larger disasters (i.e., lower quantiles) where disaster preparedness appears to be less effective. Hence these two policies seem to be complementary, with their relative effectiveness varying across the growth distribution or the size of the underlying shock.

Our findings underscore the importance of both disaster preparedness and fiscal space to mitigate the impact of natural disasters on growth. While higher disaster preparedness is particularly helpful for small to mid-size disasters, it is important to maintain fiscal buffers to meet capital investment needs after large natural disasters. Our findings suggest that fiscal rules (such as debt targets) to anchor fiscal policy should take into consideration the impact of natural disaster on growth, and hence should be set at more prudent levels in countries that are highly vulnerable to disasters, especially high-intensity ones, compared to countries that are not prone to large disaster shocks. ${ }^{20}$

\footnotetext{
${ }^{20}$ This is consistent with Eyraud and others (2018) which notes that fiscal frameworks should include a debt anchor as a medium-term objective, combined with flexibility mechanisms that allow the response to shocks, such as natural disasters.
} 


\section{REFERENCES}

Adrian, Tobias, N. Boyarchenko, and D. Giannone. 2019. "Vulnerable Growth" American Economic Review 109(4)

Adrian, Tobias, F. Grinberg, N. Liang, and S. Malik. 2018. "The Term Structure of Growthat-Risk", IMF Working Paper 18/180, International Monetary Fund, Washington, DC.

Berlemann, Michael, and D. Wenzel. 2016. "Long-term Growth Effects of Natural Disasters - Empirical Evidence for Droughts," Economics Bulletin, AccessEcon, vol. 36(1), pages $464-476$.

Caballero, Ricardo J., and M. Hammour. 1994. "The Cleansing Effect of Recessions." A.E.R. 84: 1350-68

Cantelmo, A., G. Melina, and C. Papageorgiou. 2019. "Macroeconomic Outcome in Disaster Prone Countries.” IMF Working Paper, WP/19/217. Washington D.C.

Cavallo, E., Galiani, S., I. Noy, and J. Pantano. 2013. Catastrophic Natural Disasters and Economic Growth. Review of Economics and Statistics, 95(5), 1549-1561.

Cavallo, E., and I. Noy. 2011. Natural Disasters and the Economy-A Survey. International Review of Environmental and Resource Economics, 5(1), 63-102.

EM-DAT. 2018. The International Disaster Database https://www.emdat.be/database

Eyraud, L., X. Debrun, A. Hodge, V. D. Lledo, and C. Pattillo. 2018. Second Generation Fiscal Rules: Balancing Simplicity, Flexibility and Enforceability, Staff Discussion Note: 18/04, International Monetary Fund, Washington D.C.

Felbermayr, G., and J. Gröschl. 2014. Naturally Negative: The Growth Effects of Natural Disasters. Journal of Development Economics, 111, 92-106.

Guo, W., and S. Quayyum. 2020. "Building Resilience to Natural Disasters in Vulnerable States: Savings from Ex-Ante Actions.” Well Spent: How Strong Governance Can End Waste in Public Investment, Chapter 9. Washington D.C., September 2020

Hallegatte S, J-C. Hourcade, and P. Dumas. 2007. Why economic dynamics matter in assessing climate change damages: illustration on extreme events. Ecol Econ 62(2):330-340 
Hochrainer, S., 2009. Assessing the Macroeconomic Impact of Natural Disasters: Are There Any? World Bank Policy Research Working Paper, 4968, World Bank, Washington.

International Monetary Fund. 2019. Building Resilience in Developing Countries Vulnerable to Large Natural Disasters, IMF Policy Papers, Washington:

International Monetary Fund. 2018. Dominica Staff Report for the 2018 Article IV Consultation, IMF Country Report No. 18/265, Washington:

International Monetary Fund. 2017. The Effects of Weather Shocks on Economic Activity: How Can Low-Income Countries Cope? Chapter 3 of World Economic Outlook: Seeking Sustainable Growth: Short-Term Recovery, Long-Term Challenges, October, Washington.

Kossin, J. P., K. A. Emanuel, and G. A. Vecchi, 2014: The poleward migration of the location of tropical cyclone maximum intensity. Nature, 509, 349-352.

Knutson, T. R., and others. 2013. Dynamical downscaling projections of twenty-first-century Atlantic hurricane activity: CMIP3 and CMIP5 model-based scenario. J. Climate, $26,6591-6617$

Lee D., I. Zhang, and C. Nguyen. 2018. The Economic Impact of Natural Disasters in Pacific Island Countries: Adaptation and Preparedness. IMF WP/18/108.

Loayza, N., E. Olaberria, J. Rigolini, and L. Christiaensen. 2012. Natural Disasters and Growth: Going beyond the Averages. World Development, 40(7), 1317-1336.

Marto, Ricardo, C. Papageorgiou, and V. Kluyev. 2018. "Building Resilience to Natural Disasters: An Application to Small Developing States." Journal of Development Economics, Vol. 135, pages 574-586.

Mechler, R. 2009. - Disasters and Economic Welfare: Can National Savings Help Explain Post Disaster Changes in Consumption? ॥ World Bank Policy Research Working Paper 4988.

Noy, Ilan. 2009. The Macroeconomic Consequences of Disasters. Journal of Development Economics, 88(2), 221-231.

Noy, Ilan, and A. Nualsri. 2007. "What Do Exogenous Shocks Tell Us about Growth Theories?" University of Hawaii working paper 07-28. 
Powell, David. 2015. "Quantile Regression with Non-Additive Fixed Effects," RAND Corporation Working Paper.

Raddatz, Claudio. 2009. "The Wrath of God: Macroeconomic Costs of Natural Disasters," World Bank policy research working paper 5039.

Rodriguez-Oreggia, E., A. de la Fuente, and R. de la Torre, and others. 2013. "The Impact of Natural Disasters on Human Development and Poverty at the Municipal Level in Mexico." The Journal of Development Studies, 49(3), 442-455.

Standard and Poor's Rating Services. 2015. "Storm Alert: Natural Disasters Can Damage Sovereign Creditworthiness," RatingsDirect, September

Skidmore, M, and H. Toya. 2002. "Do Natural Disasters Promote Long- Run Growth?" Economic Inquiry 40, 664-687.

Strobl, E. 2012. "The Economic Growth Impact of Natural Disasters in Developing Countries: Evidence from Hurricane Strikes in the Central American and Caribbean Regions," Journal of Development Economics, vol. 97, pp. 131-140.

UNISDR. 2020. United Nations International Strategy for Disaster Reduction, Database. https://www.unisdr.org/we/inform/disaster-statistics

World Bank. 2017. Pacific Possible: Long-term Economic Opportunities and Challenges for Pacific Island Countries. Pacific Possible Series, World Bank Group, Washington. 


\begin{tabular}{|c|c|c|c|c|c|c|}
\hline \multicolumn{7}{|c|}{ Table 1. Impact of Natural Disaster on Growth in the Year of Disaster } \\
\hline & (1) & (2) & (3) & (4) & (5) & (6) \\
\hline VARIABLES & OLS & 10th & 25th & 50th & 75th & 90th \\
\hline Growth (lagged) & $\begin{array}{l}0.220^{* * *} \\
(0.0535)\end{array}$ & $\begin{array}{l}0.302^{* * *} \\
(0.0133)\end{array}$ & $\begin{array}{l}0.303^{* * *} \\
(0.0123)\end{array}$ & $\begin{array}{l}0.267^{* * *} \\
(0.0140)\end{array}$ & $\begin{array}{l}0.238^{\star * *} \\
(0.0102)\end{array}$ & $\begin{array}{c}0.212^{\star * *} \\
(0.00772)\end{array}$ \\
\hline Natural Disaster & $\begin{array}{c}-0.00771^{* * *} \\
(0.00281)\end{array}$ & $\begin{array}{c}-0.00927^{* * *} \\
(0.00192)\end{array}$ & $\begin{array}{c}-0.00856^{* * *} \\
(0.00110)\end{array}$ & $\begin{array}{l}-0.00777^{\star \star \star *} \\
(0.000684)\end{array}$ & $\begin{array}{l}-0.00484^{* * *} \\
(0.000766)\end{array}$ & $\begin{array}{l}-0.00442^{* *} \\
(0.00186)\end{array}$ \\
\hline Observations & 3,612 & 3,612 & 3,612 & 3,612 & 3,612 & 3,612 \\
\hline R-squared & 0.154 & & & & & \\
\hline Number of ifscodes & 151 & 151 & 151 & 151 & 151 & 151 \\
\hline Country Fixed Effect & Yes & Yes & Yes & Yes & Yes & Yes \\
\hline Time Fixed Effect & Yes & Yes & Yes & Yes & Yes & Yes \\
\hline \multicolumn{7}{|c|}{$\begin{array}{l}\text { Robust standard errors in parentheses } \\
{ }^{* * *} p<0.01,{ }^{* *} p<0.05,{ }^{*} p<0.1\end{array}$} \\
\hline
\end{tabular}

\begin{tabular}{|c|c|c|c|c|c|c|}
\hline \multicolumn{7}{|c|}{ Table 2. Impact of Large Natural Disaster on Growth by Disaster Type } \\
\hline \multirow[b]{3}{*}{ VARIABLES } & (1) & $(2)$ & (3) & (4) & (5) & (6) \\
\hline & \multicolumn{6}{|c|}{ Dependent Variable: GDP per capita growth } \\
\hline & OLS & 10th & 25th & 50th & 75th & 90th \\
\hline \multirow[t]{2}{*}{ Lagged Growth } & $0.223 * * *$ & $0.299 * * *$ & $0.295 * * *$ & $0.429 * * *$ & $0.326 * * *$ & $0.213 * * *$ \\
\hline & $(0.0506)$ & $(0.0129)$ & $(0.00968)$ & $(0.00300)$ & $(0.0179)$ & $(0.00964)$ \\
\hline \multirow[t]{2}{*}{ Storm } & $-0.00803 * *$ & -0.00603 & $-0.00823 * * *$ & $-0.0103 * * *$ & $-0.00533 * *$ & $-0.0112 * * *$ \\
\hline & $(0.00366)$ & $(0.00385)$ & $(0.00212)$ & $(0.00107)$ & $(0.00249)$ & $(0.00118)$ \\
\hline \multirow[t]{2}{*}{ Flood } & $-0.00753^{*}$ & $-0.0142 * * *$ & $-0.0156 * * *$ & $-0.00487 * * *$ & $-0.0126 * * *$ & $-0.00784 * * *$ \\
\hline & $(0.00390)$ & $(0.00482)$ & $(0.00494)$ & $(0.000885)$ & $(0.00125)$ & $(0.00167)$ \\
\hline \multirow[t]{2}{*}{ Drought } & -0.00152 & 0.000966 & -0.00196 & -0.00272 & -0.00240 & $0.00525 * *$ \\
\hline & $(0.00427)$ & $(0.00365)$ & (0.00148) & $(0.00168)$ & $(0.00184)$ & $(0.00260)$ \\
\hline \multirow[t]{2}{*}{ Earthquake } & -0.0330 & $-0.0778 * * *$ & $-0.0350 *$ & $0.00752^{* * *}$ & $0.0273 * * *$ & $0.0143 * * *$ \\
\hline & $(0.0216)$ & $(0.00851)$ & $(0.0180)$ & $(0.00273)$ & $(0.00652)$ & $(0.00452)$ \\
\hline \multirow[t]{2}{*}{ Constant } & $0.0110 * * *$ & & & & & \\
\hline & $(0.00254)$ & & & & & \\
\hline Observations & 3,612 & 3,612 & 3,612 & 3,612 & 3,612 & 3,612 \\
\hline R-squared & 0.155 & & & & & \\
\hline Number of countries & 151 & 151 & 151 & 151 & 151 & 151 \\
\hline \multicolumn{7}{|c|}{$\begin{array}{l}\text { Robust standard errors in parentheses. Number of droughts in the sample is } 94, \text { number of floods is } 66, \text { number of storms } \\
\text { is } 68 \text { and number of earthquake is } 14 . \\
* * * p<0.01, * * p<0.05, * p<0.1\end{array}$} \\
\hline
\end{tabular}




\begin{tabular}{|c|c|c|c|c|c|}
\hline \multicolumn{6}{|c|}{ Table 3. Disaster Preparedness and Impact of Natural Disaster on Growth } \\
\hline \multirow[b]{3}{*}{ VARIABLES } & 1 & 2 & 3 & 4 & 5 \\
\hline & \multicolumn{5}{|c|}{$\begin{array}{c}\text { Dependent Variable: Growth of GDP per capita } \\
\text { Quantile: }\end{array}$} \\
\hline & 10th & 25th & 50th & 75th & 90th \\
\hline Growth of GDP per capita (lagged) & $\begin{array}{l}0.158^{* * *} \\
(0.0603)\end{array}$ & $\begin{array}{l}0.148^{* * *} \\
(0.0464)\end{array}$ & $\begin{array}{l}0.0543 \\
(0.0440)\end{array}$ & $\begin{array}{l}0.0130 \\
(0.0512)\end{array}$ & $\begin{array}{l}0.0420 \\
(0.0808)\end{array}$ \\
\hline Natural Disaster & $\begin{array}{l}-0.00121 \\
(0.0530)\end{array}$ & $\begin{array}{l}-0.0353 \\
(0.0420)\end{array}$ & $\begin{array}{l}-0.0601^{* *} \\
(0.0291)\end{array}$ & $\begin{array}{c}-0.0726^{* * *} \\
(0.0186)\end{array}$ & $\begin{array}{c}-0.0843^{* *} \\
(0.0389)\end{array}$ \\
\hline HFA Index & $\begin{array}{c}0.00147 \\
(0.00128)\end{array}$ & $\begin{array}{l}0.00185^{* *} \\
(0.000912)\end{array}$ & $\begin{array}{l}0.00258^{\star * *} \\
(0.000536)\end{array}$ & $\begin{array}{c}0.00304^{* * *} \\
(0.00113)\end{array}$ & $\begin{array}{l}0.00209^{* *} \\
(0.00104)\end{array}$ \\
\hline Natural Disaster * HFA Index & $\begin{array}{r}-0.000486 \\
(0.00340)\end{array}$ & $\begin{array}{c}0.00141 \\
(0.00262)\end{array}$ & $\begin{array}{l}0.00323^{*} \\
(0.00182)\end{array}$ & $\begin{array}{r}0.00412^{* * *} \\
(0.00107)\end{array}$ & $\begin{array}{l}0.00568^{\star *} \\
(0.00259)\end{array}$ \\
\hline Observations & 522 & 522 & 522 & 522 & 522 \\
\hline Number of groups & 120 & 120 & 120 & 120 & 120 \\
\hline $\begin{array}{l}\text { Robust standard errors in parenthese } \\
{ }^{* * *} p<0.01,{ }^{* *} p<0.05,{ }^{*} p<0.1\end{array}$ & clude time & ountry fixe & fects. & & \\
\hline
\end{tabular}

\section{Table 4. Public Debt and Impact of Natural Disaster on Contemporaneous Growth}

\begin{tabular}{|c|c|c|c|c|c|}
\hline \multirow[b]{3}{*}{ VARIABLES } & \multicolumn{5}{|c|}{ Dependent Variable: Contemporaneous Growth } \\
\hline & & & Quantile: & & \\
\hline & 10th & 25th & 50th & 75th & 90th \\
\hline Growth (lagged) & $\begin{array}{l}0.104^{* * *} \\
(0.0309)\end{array}$ & $\begin{array}{l}0.166^{* * *} \\
(0.0204)\end{array}$ & $\begin{array}{c}0.185^{\star *} \\
(0.0785)\end{array}$ & $\begin{array}{l}0.174^{* * *} \\
(0.0504)\end{array}$ & $\begin{array}{l}0.146^{* * *} \\
(0.0251)\end{array}$ \\
\hline Natural Disaster & $\begin{array}{l}0.000610 \\
(0.00514)\end{array}$ & $\begin{array}{l}0.00873^{*} \\
(0.00507)\end{array}$ & $\begin{array}{c}0.0205 \\
(0.0129)\end{array}$ & $\begin{array}{l}0.0308^{\star * *} \\
(0.00900)\end{array}$ & $\begin{array}{c}-0.0222 \\
(0.0202)\end{array}$ \\
\hline Log of Public Debt (lagged) & $\begin{array}{c}-0.00326^{\star * *} \\
(0.000916)\end{array}$ & $\begin{array}{c}-0.00260^{* * *} \\
(0.000469)\end{array}$ & $\begin{array}{c}-0.000253 \\
(0.000393)\end{array}$ & $\begin{array}{c}-1.28 \mathrm{e}-05 \\
(0.00162)\end{array}$ & $\begin{array}{l}0.000509 \\
(0.00141)\end{array}$ \\
\hline Natural Disaster * Log of Public Debt (lagged) & $\begin{array}{l}-0.00218^{*} \\
(0.00116)\end{array}$ & $\begin{array}{c}-0.00471^{* * *} \\
(0.00129)\end{array}$ & $\begin{array}{l}-0.00761^{* *} \\
(0.00308)\end{array}$ & $\begin{array}{r}-0.00884^{* * *} \\
(0.00224)\end{array}$ & $\begin{array}{c}0.00612 \\
(0.00545)\end{array}$ \\
\hline Observations & 2,779 & 2,779 & 2,779 & 2,779 & 2,779 \\
\hline Number of countries & 146 & 146 & 146 & 146 & 146 \\
\hline $\begin{array}{l}\text { Robust standard errors in parentheses } \\
{ }^{* * *} p<0.01,{ }^{* *} p<0.05,{ }^{*} p<0.1\end{array}$ & & & & & \\
\hline ource: Authors' Calculations & & & & & \\
\hline
\end{tabular}




\begin{tabular}{|c|c|c|c|c|c|}
\hline \multirow[b]{2}{*}{ VARIABLES } & \multicolumn{5}{|c|}{$\begin{array}{c}\text { Dependent Variable: Growth (Two Years Ahead) } \\
\text { Quantile: }\end{array}$} \\
\hline & 10th & 25th & 50th & 75th & 90th \\
\hline Growth (lagged) & $\begin{array}{l}0.0393^{*} \\
(0.0237)\end{array}$ & $\begin{array}{l}0.0439^{* *} \\
(0.0173)\end{array}$ & $\begin{array}{l}0.0785^{\star \star \star} \\
(0.00664)\end{array}$ & $\begin{array}{l}0.0866^{* * *} \\
(0.00426)\end{array}$ & $\begin{array}{l}0.0858^{*}+* \\
(0.0063 \$)\end{array}$ \\
\hline Natural Disaster & $\begin{array}{c}0.00173 \\
(0.00998)\end{array}$ & $\begin{array}{l}0.0273^{\star \star *} \\
(0.00352)\end{array}$ & $\begin{array}{l}0.0548^{* * *} \\
(0.00509)\end{array}$ & $\begin{array}{l}0.0287^{\star \star *} \\
(0.00790)\end{array}$ & $\begin{array}{r}0.0168 \\
(0.0137)\end{array}$ \\
\hline Log of Public Debt (lagged) & $\begin{array}{l}0.00635^{\star *} \\
(0.00323)\end{array}$ & $\begin{array}{c}0.00107 \\
(0.000694)\end{array}$ & $\begin{array}{r}0.00915^{* * *} \\
(0.00142)\end{array}$ & $\begin{array}{l}0.0125^{\star * *} \\
(0.000367)\end{array}$ & $\begin{array}{r}0.008699^{*} \\
(0.0018\rceil)\end{array}$ \\
\hline Natural Disaster * Log of Public Debt (lagged) & $\begin{array}{l}0.000651 \\
(0.00274)\end{array}$ & $\begin{array}{c}-0.00553^{* * *} \\
(0.00103)\end{array}$ & $\begin{array}{l}-0.0119^{* * *} \\
(0.00203)\end{array}$ & $\begin{array}{c}-0.00729^{* * *} \\
(0.00224)\end{array}$ & $\begin{array}{r}-0.0045 \phi \\
(0.0034 \phi)\end{array}$ \\
\hline $\begin{array}{l}\text { Observations } \\
\text { Number of countries }\end{array}$ & $\begin{array}{c}2,495 \\
146\end{array}$ & $\begin{array}{c}2,495 \\
146\end{array}$ & $\begin{array}{c}2,495 \\
146\end{array}$ & $\begin{array}{c}2,495 \\
146\end{array}$ & $\begin{array}{c}2,495 \\
146\end{array}$ \\
\hline \multicolumn{6}{|l|}{$\begin{array}{l}\text { Robust standard errors in parentheses } \\
{ }^{* * *} p<0.01,{ }^{* *} p<0.05,{ }^{*} p<0.1\end{array}$} \\
\hline & \multicolumn{5}{|c|}{$\begin{array}{c}\text { Dependent Variable: Growth (One Year Ahead) } \\
\text { Quantile: }\end{array}$} \\
\hline VARIABLES & 10th & 25th & 50th & 75th & 90th \\
\hline Growth (lagged) & $\begin{array}{l}-0.0375 \\
(0.0303)\end{array}$ & $\begin{array}{c}0.0296 \\
(0.0192)\end{array}$ & $\begin{array}{l}0.0771^{* * *} \\
(0.0128)\end{array}$ & $\begin{array}{c}0.112^{* * *} \\
(0.000926)\end{array}$ & $\begin{array}{l}0.0890^{* * *} \\
(0.00792)\end{array}$ \\
\hline Natural Disaster & $\begin{array}{l}0.0234^{* * *} \\
(0.00705)\end{array}$ & $\begin{array}{l}0.0235^{* * *} \\
(0.00691)\end{array}$ & $\begin{array}{l}0.0248^{* * *} \\
(0.00738)\end{array}$ & $\begin{array}{c}0.00239^{* *} \\
(0.000930)\end{array}$ & $\begin{array}{l}-0.0120 \\
(0.0124)\end{array}$ \\
\hline Log of Public Debt (lagged) & $\begin{array}{c}0.00134 \\
(0.00188)\end{array}$ & $\begin{array}{c}0.000329 \\
(0.000436)\end{array}$ & $\begin{array}{l}0.00369^{* * *} \\
(0.000513)\end{array}$ & $\begin{array}{l}-0.00801^{* * *} \\
(0.000103)\end{array}$ & $\begin{array}{r}0.00539^{* * *} \\
(0.00206)\end{array}$ \\
\hline Natural Disaster * Log of Public Debt (lagged) & $\begin{array}{c}-0.00455^{\star *} \\
(0.00202)\end{array}$ & $\begin{array}{c}-0.00471^{* * *} \\
(0.00153)\end{array}$ & $\begin{array}{c}-0.00496^{* *} \\
(0.00194)\end{array}$ & $\begin{array}{l}-0.00161^{* * *} \\
(0.000251)\end{array}$ & $\begin{array}{c}0.00465 \\
(0.00349)\end{array}$ \\
\hline Observations & 2,641 & 2,641 & 2,641 & 2,641 & 2,641 \\
\hline Number of countries & 146 & 146 & 146 & 146 & 146 \\
\hline \multicolumn{6}{|l|}{$\begin{array}{l}\text { Robust standard errors in parentheses } \\
{ }^{* * *} p<0.01,{ }^{* *} p<0.05,{ }^{*} p<0.1\end{array}$} \\
\hline Source: Authors' Calculations. & & & & & \\
\hline
\end{tabular}


Table 6. Investment Growth and Natural Disaster

\begin{tabular}{|c|c|c|c|c|c|}
\hline \multirow{3}{*}{ VARIABLES } & \multicolumn{5}{|c|}{ Dependent Variable: Investment Growth (Contemporaneous) } \\
\hline & \multicolumn{5}{|c|}{ Quantile: } \\
\hline & 10th & 25th & 50th & 75th & 90th \\
\hline \multirow[t]{2}{*}{ Investment Growth (lagged) } & $0.0352^{* *}$ & $0.0347^{\star *}$ & $0.0428^{\star * *}$ & $0.0344^{\star * *}$ & $0.0206^{* * *}$ \\
\hline & $(0.0146)$ & $(0.0143)$ & $(0.00564)$ & $(0.0128)$ & $(0.00508)$ \\
\hline \multirow[t]{2}{*}{ Natural Disaster } & -6.607 & 2.348 & $5.825^{\star}$ & -3.308 & 6.790 \\
\hline & $(4.693)$ & $(5.930)$ & $(2.979)$ & $(6.905)$ & $(4.698)$ \\
\hline \multirow[t]{2}{*}{ Log of Public Debt (lagged) } & $-3.059^{* \star *}$ & $-2.389^{* * *}$ & $-1.358^{\star * *}$ & -0.103 & 0.0396 \\
\hline & $(0.455)$ & $(0.470)$ & $(0.244)$ & $(0.447)$ & $(0.902)$ \\
\hline \multirow[t]{2}{*}{ Natural Disaster * Log of Public Debt (lagged) } & 2.123 & -0.612 & $-1.519^{*}$ & 1.069 & -1.479 \\
\hline & $(1.422)$ & $(1.520)$ & $(0.809)$ & $(1.893)$ & $(1.266)$ \\
\hline \multirow[t]{3}{*}{ Observations } & 2,015 & 2,015 & 2,015 & 2,015 & 2,015 \\
\hline & \multicolumn{5}{|c|}{ Dependent Variable: Investment Growth (One Year Ahead) } \\
\hline & & & Quantile: & & \\
\hline VARIABLES & 10th & 25th & 50th & 75th & 90th \\
\hline \multirow[t]{2}{*}{ Investment Growth (lagged) } & -0.0212 & -0.00953 & 0.00631 & $0.0285^{\star \star *}$ & $0.0198^{* * *}$ \\
\hline & $(0.0186)$ & $(0.0114)$ & $(0.0116)$ & $(0.00965)$ & $(0.00518)$ \\
\hline \multirow[t]{2}{*}{ Natural Disaster } & $33.67^{\star \star *}$ & $15.58^{\star \star \star}$ & $9.360^{\star * *}$ & $6.368^{\star \star \star}$ & $-5.846^{\star}$ \\
\hline & $(7.112)$ & $(4.712)$ & $(2.938)$ & $(1.872)$ & $(3.354)$ \\
\hline \multirow[t]{2}{*}{ Log of Public Debt (lagged) } & $0.871^{\star *}$ & 0.219 & $0.928^{* * *}$ & $2.013^{* * *}$ & $2.463^{\star * *}$ \\
\hline & $(0.419)$ & $(0.273)$ & $(0.267)$ & $(0.266)$ & $(0.630)$ \\
\hline \multirow{2}{*}{ Natural Disaster * Log of Public Debt (lagged) } & $-8.343^{* * *}$ & $-3.120^{* *}$ & $-2.053^{* * *}$ & -0.572 & $2.705^{\star \star *}$ \\
\hline & $(1.864)$ & $(1.440)$ & $(0.724)$ & $(0.624)$ & $(0.834)$ \\
\hline \multirow[t]{3}{*}{ Observations } & 1,891 & 1,891 & 1,891 & 1,891 & 1,891 \\
\hline & Depenc & ent Variable: & vestment Gro & (Two Year & Ahead) \\
\hline & & & Quantile: & & \\
\hline VARIABLES & 10th & 25th & 50 th & 75th & 90th \\
\hline \multirow[t]{2}{*}{ Investment Growth (lagged) } & $-0.0317^{* * *}$ & $-0.0249^{* * *}$ & $-0.0212^{\star \star *}$ & $-0.0227^{* *}$ & $-0.0455^{\star * *}$ \\
\hline & $(0.00496)$ & $(0.00945)$ & $(0.00568)$ & $(0.00905)$ & $(0.00333)$ \\
\hline \multirow[t]{2}{*}{ Natural Disaster } & $36.06^{* * *}$ & $24.66^{* * *}$ & $15.30^{\star * *}$ & 2.062 & $-18.39^{* * *}$ \\
\hline & $(4.276)$ & $(3.970)$ & $(2.007)$ & $(2.200)$ & $(6.426)$ \\
\hline \multirow[t]{2}{*}{ Log of Public Debt (lagged) } & 0.448 & 0.403 & $1.467^{* *}$ & 0.322 & $1.862^{\star \star *}$ \\
\hline & $(0.806)$ & $(0.383)$ & $(0.588)$ & $(0.477)$ & $(0.603)$ \\
\hline \multirow[t]{2}{*}{ Natural Disaster * Log of Public Debt (lagged) } & $-10.76^{\star \star \star}$ & $-6.243^{\star \star *}$ & $-4.075^{\star * *}$ & -0.480 & $4.805^{\star \star}$ \\
\hline & $(1.583)$ & $(1.217)$ & $(0.622)$ & $(0.627)$ & $(1.867)$ \\
\hline Observations & 1,771 & 1,771 & 1,771 & 1,771 & 1,771 \\
\hline \multicolumn{6}{|l|}{$\begin{array}{l}\text { Robust standard errors in parentheses } \\
{ }^{* * *} p<0.01,{ }^{* *} p<0.05,{ }^{*} p<0.1\end{array}$} \\
\hline
\end{tabular}




\begin{abstract}
APPENDiX I
We apply a smoothing technique to the quantile regression estimates to derive the probability distribution function shown in Figures 8 and 10 in the main text following IMF (2017). The technique fits a skewed $t$ distribution by choosing four parameters of the distribution by minimizing the squared difference between the estimated quantile function $\left(\hat{y}_{t+h, q}\right.$ from estimating equation 1) and theoretical quantile function $y_{q}^{f}\left(\mu_{t+h}, s_{t+h}, v_{t+h}, \eta_{t+h}\right)$. The four parameters $(\mu, s, v, \eta)$ are, respectively, the location, scale, degrees of freedom and the shape of the skewed $t$ distribution. Specifically, we estimate the parameters as follows:

$$
\begin{gathered}
\left\{\mu_{t}, s_{t}, v_{t}, \eta_{t}\right\}= \\
\operatorname{argmin}_{\mu_{t}, s_{t}, v_{t}, \eta_{t}} \Sigma_{q}\left\{\hat{y}_{t, q}-y_{q}^{f}\left(\mu_{t}, s_{t}, v_{t}, \eta_{t}\right)\right\}^{2}
\end{gathered}
$$

in which $\mu_{t} \in \mathbb{R}, s_{t}>0, v_{t} \geq 2$ and $\eta_{t}>0$.
\end{abstract}

